\title{
Do the Firm Size, Debt Level, and Liquidity Have Impact on the Hedging Decisions
}

\author{
Wisnu Setiyono ${ }^{1)}$, Detak Prapanca ${ }^{* 2}$, Novita Afelya Pramudita ${ }^{* 3)}$

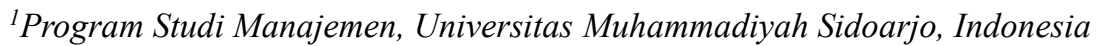 \\ ${ }^{2}$ Program Studi Manajemen, Universitas Muhammadiyah Sidoarjo, Indonesia \\ ${ }^{3}$ Program Studi Manajemen, Universitas Muhammadiyah Sidoarjo, Indonesia \\ Email:wisnu.setiyono@umsida.ac.id
}

\begin{abstract}
Hedging is an alternative to risk management in dealing with losses that happened to the company which conducts international trade. This study's purpose is to analyze the influence of firm size, debt level, and liquidity on hedging decisions in manufacturing companies listed on the Indonesian Stock Exchange in the period 2014-2018. The object of research is manufacturing companies listed on the Indonesia Stock Exchange in the period 2014-2018, with research samples obtained through purposive sampling as many as 90 companies were sampled. The data use taken from the secondary financial statement (annual report). The data were analyzed using logistic regression with the assistance of SPSS. The results of this study prove that partially, firm size and liquidity has an influence on hedging decision. Meanwhile, debt level does not affect hedging decisions. At the same time, the variabels of firm size, debt level, and liquidity have a simultaneous influence on hedging decisions.
\end{abstract}

Keywords: hedging, firm size, debt level, liquidity.

\section{INTRODUCTION}

International trade appears as one of the effects of sophisticated communication technology in the era of globalization. However, companies that trade internationally may experience more complicated problems due to the use of different currencies in each country in the payment and purchase of products [21]. Currency exchange rates can fluctuate at any time due to demand and supply [19]. Meanwhile, according to [15], if one currency's price becomes more expensive against other currencies, that currency is appreciated. On the contrary, if one currency's price falls against another currency, that currency is said to be depreciating. So the most prominent risk that a company will bear is the uncertainty of foreign exchange rates. Changes in foreign exchange rates that are not previously anticipated will affect prices, sales, and exporters' profits [13]. [15] states that the foreign exchange rate is the price of a country's currency in commodity units (such as gold and silver) or the currency of another country.

The biggest risk faced by companies conducting international transactions is the risk of foreign exchange rates. Foreign exchange risk in international trade must be managed properly by the company to have no large losses. The dilemma that arises is that risk cannot be eliminated immediately. Still, if the company does not dare to take risks, it will lose the opportunity to get a more significant profit. Multinational companies in dealing with these risks require risk management [15]. Companies must manage risk management properly so as not to experience losses. According to Tariqullah \& Habib [3], risk management refers to the entire process that requires financial institutions to define a strategic business, identify risks and understand and control risk 
characteristics. The risk of foreign exchange fluctuations can be minimized by hedging using derivative instruments [6]. Hedging can be defined as an action to limit foreign exchange risk and exposure. This strategy reduces the risk of loss due to rising prices in the future by using derivative instruments [17]. In this study, hedging is expressed as a dummy variable. Suppose the company uses derivative instruments as hedging activity. In that case, it is assigned number 1 as the category that the company is hedging, and the company is assigned the number 0 if it does not carry out hedging activities. Hedging is a way to minimize risk using various foreign currency derivative instruments, namely, futures contracts, forward contracts, options, and swaps [22].

Firm size is a company classification based on the company's total assets. The company's size can affect the ease of a company in obtaining external and internal funding sources [1]. Spric and Sevic [7] showed that large company sizes tend to hedge because the company's operations are domestic and foreign using different currencies. Therefore, larger companies will engage in more hedging activities to protect the company from currency exchange rate fluctuations. This is consistent with research conducted [7] and research conducted by Pangestuti [12], which states that firm size variables positively affect hedging decisions using derivative instruments.

The following table shows the average financial ratios of several invoice companies listed on the IDX in 20142018 and their hedging decisions.

Table 1

Average financial ratios of several manufacturing companies and hedging decisions in 2014-2018

\begin{tabular}{|l|l|l|l|l|l|}
\hline No & Company & $\begin{array}{l}\text { Ln Total } \\
\text { Asset }\end{array}$ & DAR & CR & Description \\
\hline 1 & ALTO & 27,78 & 0,60 & 152,77 & Not Hedging \\
\hline 2 & KBLI & 28,36 & 0,35 & 273,59 & Hedging \\
\hline 3 & GGRM & 31,78 & 0,38 & 185,18 & Not Hedging \\
\hline 4 & ASII & 33,24 & 0,48 & 128,01 & Hedging \\
\hline 5 & BRAM & 29,06 & 0,34 & 193,74 & Hedging \\
\hline 6 & INDS & 28,98 & 0,36 & 363,33 & Not Hedging \\
\hline
\end{tabular}

Table 1.1 shows that ALTO has the highest DAR of 0.60 , but they are not hedged. Meanwhile, BRAM, which has the lowest DAR, is hedging. This contradicts the theory, which states that the higher the DAR, the higher the hedging activity of the company. Likewise, INDS with the highest CR value (363.33) did not perform hedging activities, while ASII with the lowest CR value (128.01) did hedging activities. This contradicts the theory, which states that the higher the $\mathrm{CR}$ value, the higher the hedging activity. Also, GGRM, which has a big firm size (31.78), does not hedge, while KBLI has a low firm size (28.36) does hedging activity. This contradicts the theory that the bigger a company is, the higher the hedging activity. This phenomenon is interesting to research further so that the researchers really decide to examine the truth of the research results in the manufacturing company sector on the Indonesia Stock Exchange with different research periods and different variables, namely in the 2014 to 2018 period with the company size variable using the Ln proxy. (total assets), debt level using the proxy debt to asset ratio
(DAR) and liquidity using the current proxy ratio. The manufacturing sector's selection is based on the consideration that companies in this sector are generally quite active in carrying out export-import activities, such as importing some of their production elements from abroad, the imported raw materials are paid in foreign currencies. In contrast, the income of manufacturing companies in Indonesia is Rupiah, so that manufacturing companies will be greatly affected by exchange rate fluctuations, which increases the risk of loss for the company.

\section{METHOD}

\section{A. Location}

The research location is in the IDX Investment Gallery - Universitas Muhammadiyah Sidoarjo in manufacturing companies listed on the Indonesia Stock Exchange for 2014 - 2018. 


\section{B. Population andSample}

This study's population was all manufacturing companies listed on the Indonesian stock exchange as many as 145 companies. The sample was determined by a purposive method with the following criteria: listed on the Indonesia Stock Exchange for the period 2014-2018, published its financial reports in the study period, namely 2014-2018, and presented complete data and financial reports in Rupiah. The sample that met these criteria is 90 companies.

\section{Type of Data Source}

This study uses quantitative methods with data in the form of numbers, which are then analyzed using statistics to show the relationship between variables and develop hypothesis results related to natural phenomena. Secondary data in this study were obtained in the form of annual financial statements of manufacturing companies for the 2014-2018 period obtained from the Indonesia Stock Exchange on campus 1, Universitas Muhammadiyah Sidoarjo.

\section{Data Collecting Technique}

Data was collected using documentary sources such as books, journals, theses, notes obtained from Indonesia Stock Exchange documents in the form of manufacturing company annual financial reports from 2014 to 2018. These financial reports were obtained from these companies' websites or Galeri Investasi BEI Universitas Muhammadiyah Sidoarjo.

\section{E. Conceptual Framework}

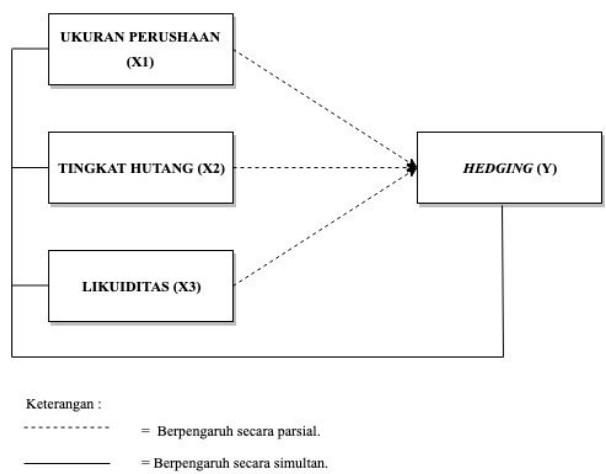

Figure 1. Conceptual Framework

\section{F. Hypotheses}

Based on the background, problem formulation, and theoretical studies described above, the hypotheses in this study are:

1. There is an effect of company size on hedging decisions.

2. There is an effect of the level of debt on the hedging decision.

3. There is an effect of liquidity on hedging decisions.

4. There are effects of forest size, debt behavior, and liquidity simultaneously on hedging decisions

\section{G. Analysis Technique}

The hypotheses in this study were tested with statistical models and data processing with the assistance of the IBM SPSS program/software 26 (Statistical Product and Service Solution).

\section{a. Descriptive Statistical Analysis}

Descriptive statistical analysis provides a description of the average (mean) data, standard deviation, maximum and minimum (Ghozali,
2006). Researchers use descriptions for variables measured on a ratio scale and frequency for variables measured on a nominal scale.

b. Logistic Regression Analysis

According to [5], binary logistic regression, or socalled logistic regression, is a method that can be used to find dichotomous relationships between dependent variables (nominal or ordinal scale 2. Category logistic regression analysis equation model, according to Ghozali [8], is as follows:

$$
\begin{aligned}
\operatorname{Ln} \frac{p}{1-p}=\beta 0+ & \beta 1 X 1+\beta 2 X 2+\cdots \\
+ & \beta k X k
\end{aligned}
$$

Description :

Ln $=$ Dependent Variable

$P=$ Probability

$\beta o=$ Regression Constant

$\beta 1, \beta 2 \ldots, \beta k=$ Regression Coefficient

$X 1, X 2,,,,, X k=$ Independent

According to [13], logistic regression analysis also requires several assumptions regarding the nature of the data, one of which is that there is no significant correlation between the independent 
variables. Therefore, this study only used one classic assumption, which is the Multicollinearity Test. There was a multicollinearity model in the model; it can be seen from the Table correlation matrix, that is, if there is an independent variable that has a correlation coefficient $>0.8$, it is said that the model contains multicollinearity.

\section{Assessing Model Fit (Overall Fit)}

The log-likelihood value indicates the overall assessment of the model $(-2 \log L$ value), that is, by comparing the $-2 \log L$ value at the beginning (blick number $=0$ ) where the model only enters a constant with the value $-2 \log L$ after the mode enters the independent variable (block number $=1$ ). If the value of $-2 \operatorname{LogL}$ block number $=0>$ the value of $-2 \operatorname{LogL}$ block number $=1$, the regression model is classified as good. Log-likelihood in logistic regression is similar to the "sum of square error" in the regression model. The decrease in loglikelihood shows that the regression model is getting better.

\section{Cox and Snell's R Square}

This measure tries to mimic the $\mathrm{R}^{2}$ measure in multiple regression based on the likelihood estimation technique with a maximum value of less than 1 (one), so it is not easy to interpret. This is done by dividing the value of cox and shell's $\mathrm{R}^{2}$ by the maximum value

Hal ini dilakukan dengan cara membagi nilai cox dan shell's $R^{2}$ dengan nilai maksimumnya

\section{Hosmer and Lemeshow's Godness of Fit} Test

If the statistical value of Hosmer and Lemeshow's Godness of Fit Test is equal to or less than 0.05 , then hypothesis 0 is rejected. There is a significant difference between the model and its observation value, so that the goodness fit is not good because the model cannot predict its observation value. Meanwhile, if the value is greater than 0.05 , the null hypothesis cannot be rejected, meaning that the model can predict the value of the observation or match the data

\section{Classification Table}

The $2 \times 2$ classification table calculates the correct and incorrect estimation values. In the column, there are two predictive values of the dependent variable, and this is vulnerable (1) and not vulnerable (0), while the row shows the real observation value of the dependent variable vulnerable (1) and not vulnerable (0).

\section{RESULT AND DISCUSSION}

\section{A. Test Result}

\section{Descriptive Statistics}

The statistical description of the object of research, in general, can be seen in the descriptive statistics table as follows:

Table 2

Descriptive Statistics

\begin{tabular}{cccccc}
\hline & $\mathrm{N}$ & Minimum & Maximum & Mean & Std.Deviation \\
\hline FS & 450 & 25.20 & 33.44 & 28.7169 & 1.62867 \\
\hline DAR & 450 & 0.07 & 5.07 & 0.5760 & 0.55752 \\
\hline CR & 450 & 10.54 & 1064.80 & 208.1655 & 168.07222 \\
\hline $\begin{array}{c}\text { Valid N } \\
\text { (listwise) }\end{array}$ & 450 & & & & \\
\hline
\end{tabular}

Source: Output SPSS

The results of the descriptive statistics table are

a. The independent variable firm size (FS) as proxied by $\mathrm{Ln}$ of total assets has an average value of 28.7169 with a standard deviation of 1.62867 .

b. The independent variable for the debt level is proxied by the debt to assets ratio (DAR), which has an average value of 0.5760 with a standard deviation of 0.55752 .

c. As proxied by the current ratio (CR), the independent variable of liquidity has an average value of 208.1655 with a standard deviation of 168.07222 . 
Table 3

Frequency Statistics

\begin{tabular}{|c|c|c|c|c|c|}
\hline & & $\begin{array}{c}\text { Frequenc } \\
\mathrm{y}\end{array}$ & Percent & $\begin{array}{c}\text { Valid } \\
\text { Percent }\end{array}$ & $\begin{array}{c}\text { Cumulative } \\
\text { Percent }\end{array}$ \\
\hline \multirow[t]{3}{*}{ Valid } & NOT HEDGING & 305 & 67.8 & 67.8 & 67.8 \\
\hline & HEDGING & 145 & 32.2 & 32.2 & 100.0 \\
\hline & Total & 450 & 100.0 & 100.0 & \\
\hline
\end{tabular}

Based on the frequency statistics table above, it can be described that the dependent variable, namely the decision to hedge, is a dummy variable where the sample companies that do hedging activities are coded "1". In contrast, the sample companies that do not do hedging activities are coded " 0 ". This variable has a valid value because all existing data can be processed with IBM SPSS 26 assistance. The number of samples of companies that perform hedging activities is 145 or $32.2 \%$ of the total sample data. In comparison, the number of companies that do not do hedging activities is 305 or $67.8 \%$.

\section{Logistic regression analysis}

The existence of a multicollinearity model in the model can be seen from the Table correlation matrix. If there are independent variables that have a correlation coefficient $>0.8$, the model contains multicollinearity. The multicollinearity test results are in the table below:

Table 4

Multicollinearity Test Results

\begin{tabular}{cccccc}
\hline & & Constant & FS & DAR & CR \\
\hline \multirow{2}{*}{ Step 1 } & Constant & 1.000 & -0.991 & -0.218 & -0.168 \\
\hline & FS & -.0991 & 1.000 & 0.124 & 0.064 \\
\cline { 2 - 6 } & DAR & -0.218 & 0.124 & 1.000 & 0.414 \\
\cline { 2 - 6 } & CR & -0.168 & 0.064 & 0.414 & 1.000 \\
\hline
\end{tabular}

It can be concluded that this study does not have a multicollinearity problem because the value of the relationship between one independent variable and another independent variable does not exceed 0.80 . a. Model Fit Assessment

The overall model can be assessed by comparing the value of -2 Log-likelihood in Table 5 and the value of -2 Log-likelihood in Table 6 . The results of the overall model study are shown in Table 5 and Table 6 as follows:

Table 5

Block 0 Likelihood

\begin{tabular}{cccc}
\hline \multirow{2}{*}{ Iteration } & & -2 Log Likelihood & $\begin{array}{c}\text { Coefficients } \\
\text { Constans }\end{array}$ \\
\hline \multirow{2}{*}{ Step 0 } & 1 & 566.784 & -0.711 \\
\cline { 2 - 4 } & 2 & 566.680 & -0.743 \\
\cline { 2 - 4 } & 3 & 566.680 & -0.744 \\
\hline
\end{tabular}

Table 6

Block 1 Likelihood

\begin{tabular}{ccccccc}
\hline & & & & \multicolumn{3}{c}{ Coefficient } \\
\hline Iteration & & $\begin{array}{c}-2 \text { Log } \\
\text { Likelihood }\end{array}$ & Constant & FS & DAR & CR \\
\hline Step 1 & 1 & $\mathbf{5 5 4 . 3 7 3}$ & $\mathbf{- 3 . 7 8 1}$ & $\mathbf{0 . 1 1 7}$ & $\mathbf{- 0 . 0 2 6}$ & $\mathbf{- 0 . 0 0 1}$ \\
\cline { 2 - 7 } & $\mathbf{2}$ & $\mathbf{5 5 3 . 5 4 8}$ & $\mathbf{- 4 . 3 0 2}$ & $\mathbf{0 . 1 3 7}$ & $\mathbf{- 0 . 0 4 5}$ & $\mathbf{- 0 . 0 0 2}$ \\
\cline { 2 - 7 } & $\mathbf{3}$ & $\mathbf{5 5 3 . 5 4 4}$ & $\mathbf{- 4 . 3 1 9}$ & $\mathbf{0 . 1 3 8}$ & $\mathbf{- 0 . 0 4 7}$ & $\mathbf{- 0 . 0 0 2}$ \\
\cline { 2 - 6 }
\end{tabular}




\begin{tabular}{llllll}
4 & 553.544 & -4.319 & 0.138 & 0.047 & -0.002 \\
\hline
\end{tabular}

The initial -2 Log Likelihood value at block number $=0$ shows a value of 565,680, while the final -2 Log Likelihood value at block number $=1$ contained in Table 4.5 gets a value of 553.544. It can be concluded that the value of -2 Log-Likelihood has decreased, indicating that the regression model is good or the hypothesized model is fit with the data.

\section{b. Cox and Snell's R-square}

The independent variable's relation to the dependent variable can be seen from the Nagelkerke R Square value. The results of the determination coefficient test are shown in Table 7.

Table 7

Cox dan Snell's R Square

\begin{tabular}{cccc}
\hline Step & -2 Log Likelihood & $\begin{array}{c}\text { Cox \& Snell R } \\
\text { Square }\end{array}$ & $\begin{array}{c}\text { Nagelkerke R } \\
\text { Square }\end{array}$ \\
\hline 1 & $553.544^{\mathrm{a}}$ & 0.027 & 0.037 \\
\hline
\end{tabular}

Nagelkerke R-Square value of 0.037 illustrates that the model has a predictive power of $3.7 \%$, which is explained by three variables: Company Size, Liquidity, and Debt Level, while other variables outside the model explain the remaining $96.3 \%$.

\section{c. Hosmer and Lemeshow's goodness of fit test}

This test serves to assess the feasibility of the regression model so that there is no difference between the model and the data so that the model can be said to be fit. The results of the Hosmer and Lemeshow's goodness of fit test are as follows:

Table 8

Hosmer and Lemeshow's Godness of Fit Test

\begin{tabular}{c|c|c|c}
\hline Step & Chi-square & df & Sig. \\
\hline 1 & 8.833 & 8 & 0.357 \\
\hline
\end{tabular}

The logistic regression model shows the Hosmer and Lemeshow Test statistical value of 8.833 with a significant probability of 0.357 . The significance value greater than 5\% indicates that this study's model is acceptable because it matches the observation data.

\section{d. Classification Table}

The classification table shows the regression model's predictive power to predict the likelihood of manufacturing companies listed on the IDX for the 20142018 period to hedge. The following are the results of the classification table:

Table 9

Classification Table

\begin{tabular}{|c|c|c|c|c|c|}
\hline \multirow[b]{2}{*}{ Observed } & & & \multicolumn{2}{|c|}{ Predicted HEDGING } & \multirow{2}{*}{$\begin{array}{c}\text { Percentage } \\
\text { Correct }\end{array}$} \\
\hline & & & NOT & HEDGING & \\
\hline \multirow{4}{*}{ Step 1} & HEDGING & NOT & 300 & 5 & 984 \\
\hline & HILEบIIV & HEDGING & & & 70.4 \\
\hline & & HEDGING & 138 & 7 & 4.8 \\
\hline & \multicolumn{2}{|c|}{ Overall Percentage } & & & 68.2 \\
\hline
\end{tabular}

The table shows that the prediction of companies' observations that did not do hedging was 305 , while the actual observation results are 300 with a classification accuracy of $98.4 \%$. Furthermore, the prediction of observations that performed hedging activity was 145 , while the observation results were only seven with an accuracy of $4.8 \%$. Thus, overall, this model's accuracy is
$68.2 \%$, which means that this study's results are quite good because they are close to $100 \%$ accurate.

\section{B. Hypothesis Test}

1. Wald Test

The partial hypothesis test can be seen in the table of variables in the equation in the significant column if the significance level is $<0.05$, which means that the independent variables have a partial effect on the 
dependent variable. Wald test results can be seen in the following table:

Table 10

Wald Test

\begin{tabular}{|c|c|c|c|c|c|c|c|c|c|}
\hline & & \multirow[b]{2}{*}{ B } & \multirow[b]{2}{*}{ S.E } & \multirow[b]{2}{*}{ Wald } & \multirow[b]{2}{*}{ df } & \multirow[b]{2}{*}{ Sig } & \multirow[b]{2}{*}{$\begin{array}{l}\text { Exp } \\
(B)\end{array}$} & \multicolumn{2}{|c|}{$\begin{array}{l}96 \% \text { C.1 for } \\
\text { EXP (B) }\end{array}$} \\
\hline & & & & & & & & Lowe & Upper \\
\hline \multirow{4}{*}{$\begin{array}{l}\text { Step } \\
1\end{array}$} & FS & 0.138 & 0.064 & 4.690 & 1 & 0.030 & 1.147 & 1.113 & 1.300 \\
\hline & DAR & -0.047 & 0.201 & 0.065 & 1 & 0.815 & 0.954 & 0.643 & 1.415 \\
\hline & $\mathrm{CR}$ & -0.002 & 0.001 & 5.170 & 1 & 0.023 & 0.998 & 0.997 & 1.000 \\
\hline & $\begin{array}{l}\text { Consta } \\
\mathrm{nt}\end{array}$ & -4.319 & 1.873 & 5.317 & 1 & 0.021 & 0.013 & & \\
\hline
\end{tabular}

Based on the logistic regression, the table shows that there are two independent variables (X) whose significance level is $<0.05$, namely the Company Size variable with a significant level of 0.030 and the Liquidity variable with a significant level of 0.023 . This means that the two independent variables (X) have a partial influence on hedging decisions. Meanwhile, the variable level of debt with a significant level of 0.815 does not partially affect the hedging decision because the significant level value is $<0.05$.
Table 4.9 produces the following logistic regression equation:

Hedging Decision $=-4,319+0,138(F S)+-0,047(D A R)$

$$
+-0,002(C R)
$$

\section{Simultaneity Test (Likelihood Ratio Test)}

Suppose the calculated chi-square value is greater than the chi-square table or a significant value, 0.05 . In that case, it can be said that there is a simultaneous influence on the independent variable on the dependent variable. This simultaneity test can be seen in Table 11 omnibus tests of model coefficients below:

Table 11

Simultaneity Test

Omnibus Tests of Model Coefficients

\begin{tabular}{lcccc}
\hline & & Chi-square & df & Sig. \\
\hline \multirow{3}{*}{ Step 1 } & Step & 12.136 & 3 & 0.007 \\
\cline { 2 - 5 } & Block & 12.136 & 3 & 0.007 \\
\cline { 2 - 5 } & Model & 12.136 & 3 & 0.007 \\
\hline
\end{tabular}

The table above shows that the calculated chi-square value is 12.136 with a significant value of 0.007 , so the considerable value $<0.005$, which means that $\mathrm{H} 1$ is accepted, H0 is rejected. In conclusion, company size, level of debt, and liquidity simultaneously influence hedging decisions in manufacturing companies listed on the IDX in 2014-2018.

\section{Discussion}

\section{The Effect of Firm Size on Hedging Decisions}

Firm size, which is proxied by the natural logarithm of total assets, affects hedging decisions in manufacturing companies listed on the IDX. The regression coefficient value is positive at 0.138 , and Wald's value is 4.690 with a significant value of 0.030 . The significant value generated by company size $<0.05$ means $\mathrm{H} 1$ is accepted and $\mathrm{HO}$ is rejected. Large companies tend to have wide operational activities domestically and abroad, so the risks they face are also greater. This large risk is caused by foreign transactions involving several different currencies in each country. Therefore, large companies tend to hedge to protect themselves from the risk of currency exchange rate fluctuations that may arise. The results of this test have the same results as [20].

\section{Effect of debt levels on hedging decisions}

The level of debt does not affect hedging decisions in manufacturing companies listed on the IDX in 2014-2018. The variable regression coefficient value is negative 0.047 and has a Wald value of 0.055 with a significant value of 0.815 . The significant value generated by the debt level is $>0.05$, which means that $\mathrm{H} 0$ is accepted and $\mathrm{H} 1$ is rejected. This shows that companies with high debt 
do not necessarily need to hedge because most of the company's debt comes from within the country. This can be because companies conducting international transactions do not have debts denominated in foreign exchange rates, so they do not need hedging.

\section{The effect of liquidity on hedging decisions}

Liquidity affects hedging decisions in manufacturing companies listed on the IDX in 2014-2018. The regression coefficient is negative at -0.002 and has a Wald value of 5.170 with a significant value of 0.023 . The significant value generated by company size is $<0.05$, which means $\mathrm{H} 1$ is accepted and $\mathrm{H} 0$ is rejected. In meeting its short-term obligations, a company will get heavier if it has short-term debt dominated by foreign currency because the value of the debt will fluctuate in line with the local currency exchange rate movement against U \$ dollars. When the Rupiah depreciates, the debt value will increase, and when the Rupiah is appreciated, the value of the debt will decrease. This situation creates a greater risk to be borne by the company so that the company is encouraged to undertake hedging, which can be done with foreign currency derivative instruments.

4. Simultaneous influence of company size, level of debt, and liquidity on hedging decisions

Company size, level of debt, and liquidity simultaneously affect hedging decisions. By obtaining the calculated chisquare value of 12.136 with a significant value of 0.007 , the considerable value $<0.005$ means that $\mathrm{H} 1$ is accepted. $\mathrm{HO}$ is rejected. This is in line with research [17], which states that internal factors influence hedging decision making, namely: debt to equity, current ratio, and firm size.

\section{CONCLUSION AND SUGGESTION}

\section{A. Conclusion}

Based on the results of the data analysis carried out in the previous chapter, the researcher can conclude that:

1. Firm size has a significant effect on hedging decisions

2. The level of debt does not affect hedging decisions

3. Liquidity has a significant effect on hedging decisions

4. Company size, level of debt, and liquidity simultaneously have a significant effect on hedging decisions

\section{B. Suggestion}

The researchers suggest that future researchers use a sample outside of manufacturing companies listed on the IDX with the most recent research year and discuss hedging that is useful for protecting interest rates.

\section{REFERENCES}

[1] Aretz, K., Bartram, S. M., \& Dufey, G. (2007). Why hedge? Rationales for corporate hedging and value implications. Journal of Risk Finance, 8(5), 434-449. https://doi.org/10.1108/15265940710834735

[2] Ariani, N., \& Sudiartha, G. (2017). Pengaruh Leverage, Profitabilitas, Dan Likuiditas Terhadap Keputusan Hedging Perusahaan Sektor Pertambangan Di Bursa Efek Indonesia. E-Jurnal Manajemen Universitas Udayana, 6(1), 347-374.

[3] Astuti, N. K. B., \& Yadnya, I. P. (2019). Pengaruh Profitabilitas, Likuiditas, Dan Ukuran Perusahaan Terhadap Nilai Perusahaan Melalui Kebijakan Dividen. E-Jurnal Manajemen Universitas Udayana, 8(5), 3275. https://doi.org/10.24843/ejmunud.2019.v08.i05.p25

[4] Astyrianti, N., \& Sudiartha, G. (2017). Pengaruh Leverage, Kesempatan Tumbuh, Kebijakan Dividen Dan Likuiditas Terhadap Keputusan Hedging Pt. Unilever Tbk. E-Jurnal Manajemen Universitas Udayana, 6(3), 1312-1339.

[5] Brigham, E., \& Houston, J. F. (2007). Dasar-dasar Manajemen Keuangan (Edisi Kesembilan). Selemba Empat.

[6] Diah Windari, I. G. M., \& Purnawati, N. K. (2019). Pengaruh Leverage, Ukuran Perusahaan, Dan Likuiditas Terhadap Keputusan Hedgingpada Perusahaan Manufaktur Terdaftar Di Bei. E-Jurnal Manajemen Universitas Udayana, 8(8), 4815. https://doi.org/10.24843/ejmunud.2019.v08.i08.p04

[7] Fitriasari, F. (2011). Value Drivers terhadap Nilai Pemegang Saham Perusahaan yang Hedging di Derivatif Valuta Asing. Jurnal Manajemen Bisnis, 1(1), 89-102.

[8] Ghozali, I. (2018). Aplikasi Analisis Multivariate dengan Program IBM SPSS 25 (Edisi Kese). Badan Penerbit Universitas Diponegoro.

[9] Griffin, R., \& Pustay, M. W. (2005). Bisnis Inernational (Edisi Keem). PT. Indeks Kelompok Gramedia.

[10] Guniarti, F. (2015). Faktor-Faktor Yang Mempengaruhi Aktivitas Hedging Dengan Instrumen Derivatif Valuta Asing. Jurnal Dinamika Manajemen, 5(1), 64-79. https://doi.org/10.15294/jdm.v5i1.3651

[11] Husnan, S. (1997). Manajemen Keuangan Teori dan Penerapan (Keempat). PT Gramedia Pustaka Utama.

[12] Krisdian, N., \& Badjra, I. (2017). Pengaruh Ukuran Perusahaan, Tingkat Hutang, Dan Kesulitan Keuangan Terhadap Keputusan Hedging Pada Perusahaan Manufaktur Indonesia. E-Jurnal Manajemen Universitas Udayana, 6(3), 1452-1477.

[13] Lesmana, N. V. D., \& Musdholifah. (2019). FaktorFaktor Internal Keputusan Hedging dan Dampaknya pada Nilai Perusahaan Miscellaneous Industry. 7, 857867.

[14] Madura, J. (2006). International Corporate Fiannce (Edisi Kede). Selemba Empat.

[15] Marcus, B. M. (2010). Dasar-dasar Manajemen Keuangan Perusahaan (Edisi Keli). Selemba Empa

[16] Raras Kinasih, D. P. K. M. (2019). Pengaruh Likuiditas, Leverage, Dan Nilai Tukar Rupiah Terhadap Penggunaan Instrumen Derivatif Sebagai Keputusan Hedging (Studi pada Bank Konvensional yang 
Terdaftar Di BEI Periode 2014-2017). Jurnal Ilmiah MEA (Manjamen, Ekonomi, \& Akntansi), 3(c), 63-80. https://doi.org/10.31955/mea.vol3.iss1.pp63-80

[17] Reni Utami Dewi, K., \& Purnawati, K. (2016). Pengaruh Market To Book Value Dan Likuiditas Terhadap Keputusan Hedging Pada Perusahaan Manufaktur Di Bei. E-Jurnal Manajemen Universitas Udayana, 5(1), 355-384.

[18] Samsul, M. (2010). Pasar Berjangka Komoditas dan Derivatif. Selemba Empat.

[19] Sarwono, J. (2006). Metode Penelitian Kualitatif \& Kuantitatif (Edisi Pert). Graha Ilmu.

[20] Saraswati, A. P. S., \& Suryantini, N. P. S. (2019). Pengaruh Leverage, Firm Size, Profitabilitas Terhadap Keputusan Hedging Pada Perusahaan Manufaktur Di Bursa Efek Indonesia. E-Jurnal Manajemen Universitas
Udayana,

$8(5)$

https://doi.org/10.24843/ejmunud.2019.v08.i05.p15

[21] Widyagoca, Ig., \& Lestari, P. (2016). Pengaruh Leverage, Growth Opportunities, Dan Liquidity Terhadap Pengambilan Keputusan Hedging Pt. Indosat Tbk. E-Jurnal Manajemen Universitas Udayana, 5(2), 1282-1308

[22] Wong, K. L. (2006). Financial management. In Professional Housing Management Practices in Hong Kong. https://doi.org/10.5005/jp/books/10677_12

[23] Yusgiantoro, P. (2004). Manajemen Keuangan Internasional. Fakultas Ekonomi UMiversitas Indonesia.

[24] Yuliati, S. H. (1998). Dasar-dasar Manajemen Keuangan Internasional (Edisi Pert). ANDI Yogyakarta. 